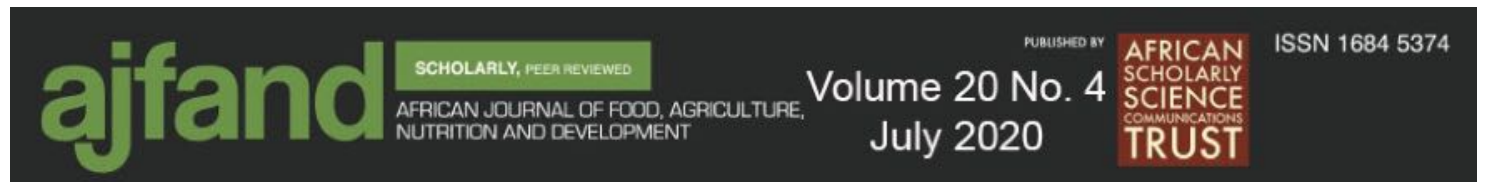

Afr. J. Food Agric. Nutr. Dev. 2020; 20(4): 16112-16126

https://doi.org/10.18697/ajfand.92.18940

\title{
NUTRITIONAL VALUE OF SELECTED WILD EDIBLE PLANTS IN TESO-KARAMOJA REGION, UGANDA
}

Ojelel $\mathbf{S}^{1 *}$, Mucunguzi $\mathbf{P}^{1}$, Kalema $\mathbf{J}^{\mathbf{1}}$, Kakudidi EK ${ }^{1}$, Namaganda $M^{1}$ and E Katuura ${ }^{1}$

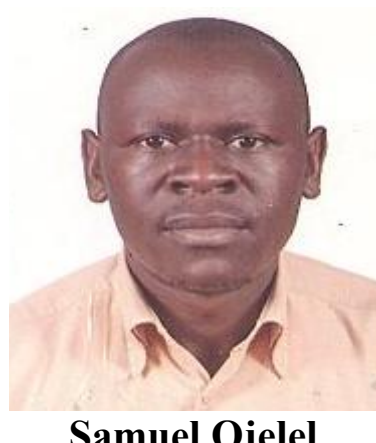

*Corresponding author email: sojelel@cns.mak.ac.ug / samojelel@gmail.com

${ }^{1}$ Makerere University, College of Natural Sciences; School of Biosciences; Department of Plant Sciences, Microbiology and Biotechnology; P.O. Box 7062 Kampala, Uganda 


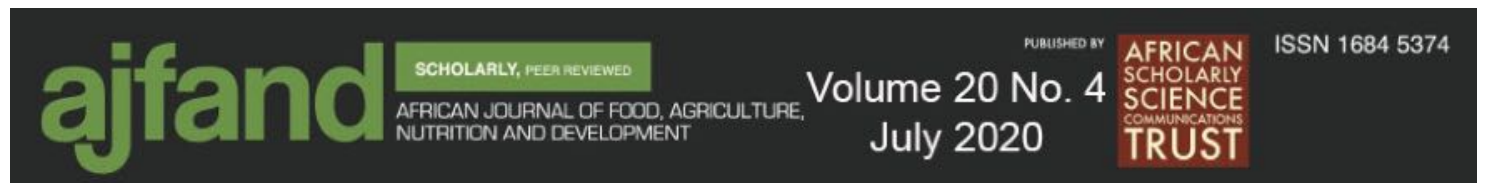

\section{ABSTRACT}

The use of wild plants for food in the rural communities of Uganda is widespread. This is attributed to food scarcity, perceived nutritional value, medicinal and health benefits and cultural preservation. However, the claims on the nutritional value of some wild edible plant species have not been fully validated. In cognizance of this, the macroelement, beta-carotene and ascorbic acid profile of five wild plants commonly used for food in and around eight forest reserves of Teso-Karamoja region, Uganda, were analysed. The plants prioritized for analysis were Vigna kirkii (Baker) J.B. Gillett, Maerua angolensis D.C., Leptadenia hastata (Schumach. \& Thonn.) Decne, Senna obtusifolia (L.) H.S. Irwin \& Barneby and Dioscorea sp.). The macro-element, ascorbic acid and beta-carotene composition of these plants was analyzed in triplicate. The variance in parameter means was analysed using one-way Analysis of Variance in SPSS ver. 16.0. The results showed that all the means of species were significantly different at the $\mathrm{p}=0.05$ level. The highest macro-nutrient means were $80.74 \pm 0.34 \% / 100 \mathrm{~g}$ moisture content in $V$. kirkii, $3.95 \pm 0.23 \mathrm{~g} / 100 \mathrm{~g}$ ash content in M. angolensis, $19.04 \pm 0.37 \mathrm{Kcal}$ gross energy in $M$. angolensis, $27.93 \pm 0.85 \mathrm{~g} / 100 \mathrm{~g}$ dietary fibre in L. hastata, $3.40 \pm 0.13$ $\mathrm{g} / 100 \mathrm{~g}$ crude fat in L. hastata, $65.43 \pm 2.91 \mathrm{~g} / 100 \mathrm{~g}$ carbohydrate in Dioscorea sp., $36.37 \pm 0.42 \mathrm{~g} / 100 \mathrm{~g}$ crude protein in $M$. angolensis. The highest ascorbic acid mean was $14.71 \pm 3.56 \mathrm{mg} / 100 \mathrm{~g}$ in $M$. angolensis while beta-carotene was $1082.1 \pm 0.08 \mu \mathrm{g} / 100 \mathrm{~g}$ in $S$. obtusifolia. These results show that these wild edible plants have a significantly variable nutritional value. Some of the macro elements can sufficiently meet the Recommended Daily Allowance (RDA) and Adequate Intakes (AI) for certain life stages and groups if consumed in ideal quantities. This information is vital in enhancing food and nutrition security awareness in the community and uplifting the social appeal and acceptability of these plants. This can be enhanced by investigating the micro-nutrients of public health significance, anti-nutrient factors, and toxic compounds in these plants.

Key words: Nutritional value, wild edible plants, macro-nutrient, ascorbic acid, betacarotene, Teso-Karamoja, Uganda 


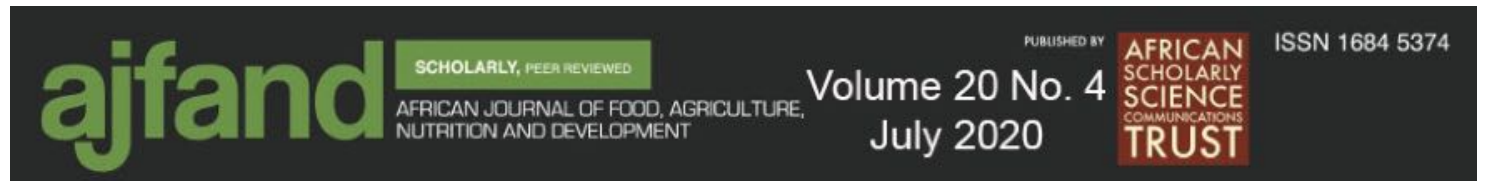

\section{INTRODUCTION}

The number of people malnourished globally is nearly one billion ( 815 million) [1]. In Uganda, an estimated 10.7 million people experienced acute food insecurity in 2017 [2]. Teso-Karamoja region was among the worst affected areas. This dire situation has generated global attention. For instance, the foundation for the 2030 Agenda for Sustainable Development and the United Nations Decade for action on Nutrition 20162025 has called upon all countries and stakeholders to act together and end hunger and prevent all forms of malnutrition by 2030 .

The use of wild edible plants is one option that developing countries can use to mitigate food insecurity and under-nutrition [3]. These plants can provide minerals, vitamins, protein, phenolics, carotenoids and carbohydrates [3,4,5]. Studies on the nutritional potential of some wild edible plants have revealed their comparability or even superiority to the domesticated crops [6]. In Ethiopia, for example, it has been suggested that most underutilized wild edible plant species can be used to mitigate micro- and macronutrient malnutrition and improve food security [7]. However, the nutritional composition of most species in different locales has not been fully characterized [8]. This is aggravated by over-exploitation and vegetation loss, which is threatening their existence before the indigenous knowledge on their use is documented and validated [9]. This calls for research to document these plants and characterize their nutritional profiles [3].

In Uganda, the consumption of wild edible plants by rural households is widespread [10]. This has been vividly affirmed by the ethnobotanical surveys conducted across the country $[11,12,13]$. However, the nutritional value of the diverse wild edible plant species has not been fully profiled [14]. Subsequently, they are neglected and undervalued in policy, research and development programming. In cognizance of this situation, the study sought to ascertain the macro-nutrient, ascorbic acid and betacarotene composition of five priority wild edible plants commonly used in TesoKaramoja region. The macro-nutrients analysed include moisture, protein, dietary fibre, gross energy, ash content, carbohydrate and crude fat. These are nutrients that the body requires in large quantities (in gram range). They are also referred to as the energy giving nutrients. The results were compared with the Recommended Daily Allowance (RDA) and Adequate Intake (AI) in order to elucidate the role of these plants in enhancing food and nutrition security. This information is crucial in enhancing nutrition awareness, uplifting the social appeal and acceptability of wild edible plants.

\section{MATERIALS AND METHODS}

\section{Study area}

The study was conducted in eight forest reserves in Teso-Karamoja region, Uganda (Figure 1). These are comprised of woodlands, shrub lands and grasslands [15]. Teso sub-region experiences a humid and hot climate with rainfall between 1000-1350 mm per annum [16]. The sub-region lies at a lower altitude than Karamoja sub-region, thereby receiving water discharges that occasionally cause flooding [16]. Karamoja, on the other hand, is mainly comprised of semi-arid lands inhabited by pastoralists and agropastoralists [17]. The lower altitude forest reserves receive variable, unpredictable and 


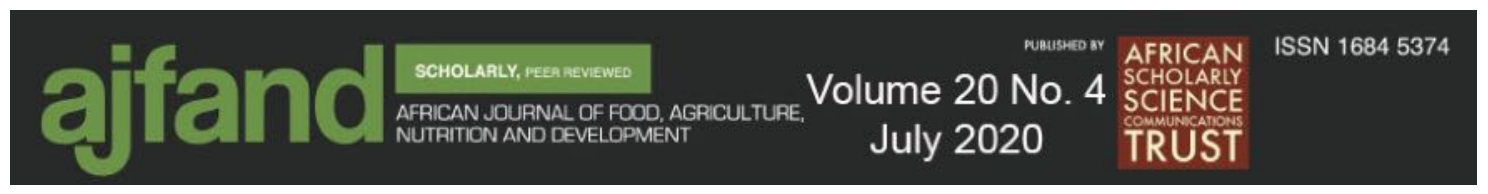

sparse rainfall ranging from 500-800 mm per annum while the highlands receive higher amounts [17]. The temperatures are generally high all year round [2].

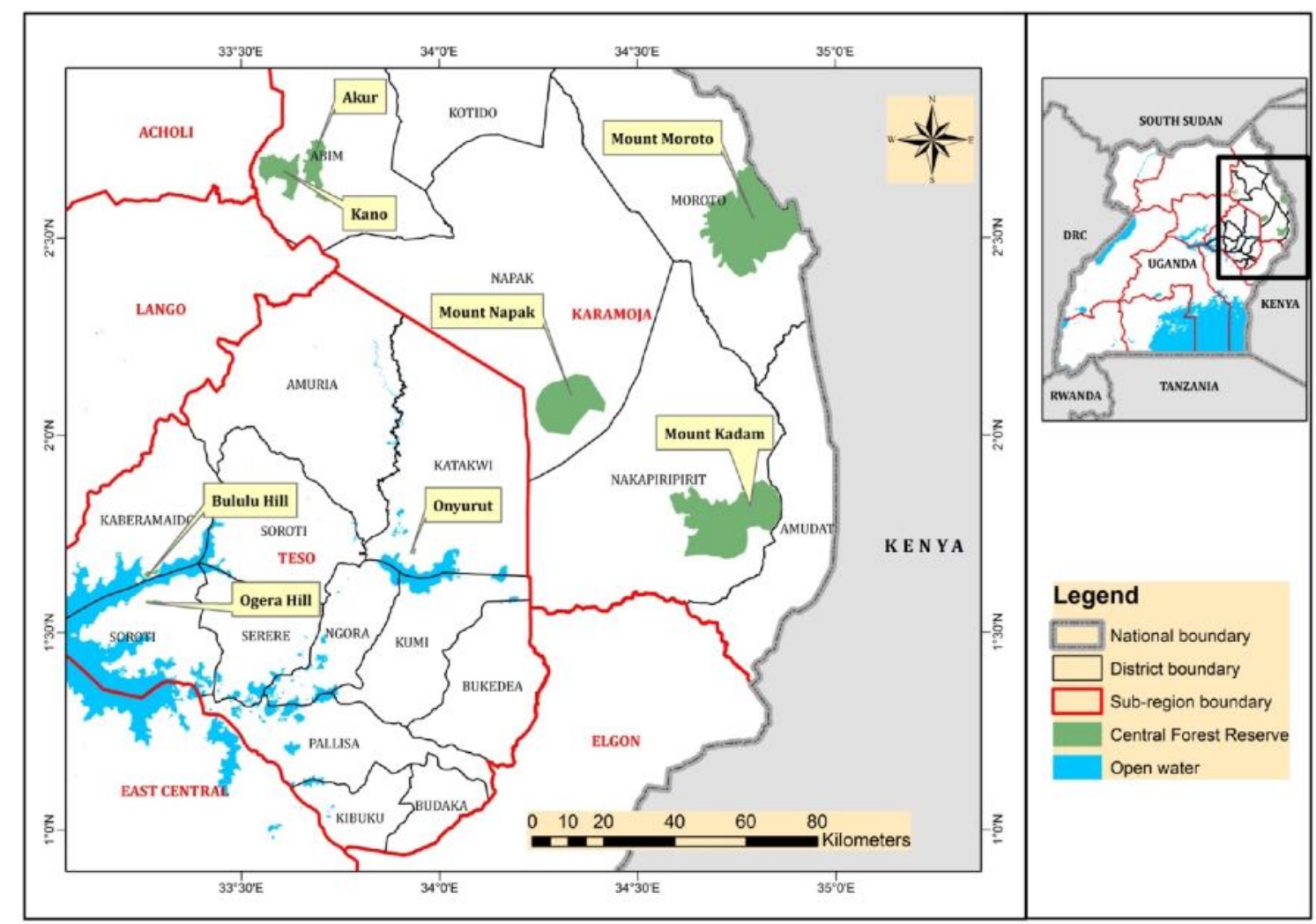

Figure 1: Location of the eight forest reserves in Teso-Karamoja region, Uganda

\section{Ethnobotanical survey}

This study was registered at the Uganda National Council for Science and Technology (UNCST/RCI/439) and permitted by the National Forestry Authority (No. 284). Semistructured questionnaires, focus group discussions and field excursions were used to collect data on wild edible plant identity. During the survey, prior informed consent and ascent of adults and children, respectively, to participate in this study was sought. Each respondent signed a consent form. The questionnaires were administered to 240 respondents living in and around eight forest reserves of Teso-Karamoja region (Figure 1) between November 2017 and May 2018. The respondents were selected using systematic simple random sampling, while the sample size was determined following Bolfarine and Bussab [18].

The free listing technique was used to record data on plant identity, edible part and mode of consumption [19]. A focus group discussion of 8-12 key respondents was conducted in each forest reserve to corroborate the information collected in the questionnaires. Thereafter, field excursions with two respondents were undertaken to collect the voucher specimens of the plants enumerated. The voucher specimens were numbered in the field, pressed, dried and identified at the Makerere University Herbarium. 


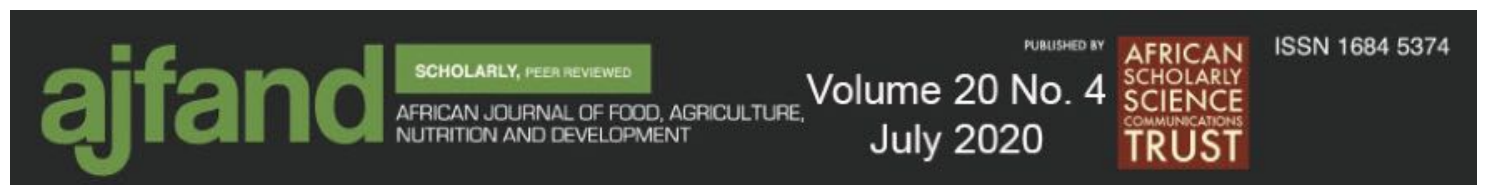

The prioritization of five wild edible plants for laboratory analysis was based on three parameters: (i) high frequency of use; (ii) paucity of information pertaining to their macro element, ascorbic acid and beta-carotene profile; and (iii) use as main sauce. After prioritization, the samples were collected from only edible portions of the plants [20].

\section{Laboratory analysis}

The analysis was carried out in triplicate for all the parameters investigated using standard methods described below. The edible plant parts analysed include young (tender) leaves (L. hastata, S. obtusifolia, V. kirkii and M. angolensis) and tubers (Dioscorea sp.).

\section{Moisture content}

Moisture was determined using the Association of Analytical Chemists (AOAC) method [21]. The percentage moisture content was then calculated using equation 1.

$$
\text { Moisture }(\%)=\frac{W_{3}-W_{1}}{W_{2}-W_{1}} \times 100 \quad \text { Equation } 1
$$

Where: $\mathrm{W}_{1}$ is weight of empty dish, $\mathrm{W}_{2}$ is weight of wet sample and dish; $\mathrm{W}_{3}$ is weight of dry sample and dish.

\section{Ash content}

Three grams of each sample were weighed, carbonated (until soot stops), and later ignited in a muffle furnace (Mustek Limited, UK) at $550^{\circ} \mathrm{C}$ for six hours following AOAC [22]. The ash content was calculated as a percentage of the total sample weight using equation 2.

$$
\% \text { ash }=\frac{W_{3}-W_{1}}{W_{2}-W_{1}} x 100 \quad \text { Equation } 2
$$

Where: $\mathrm{W}_{1}$ is weight of crucible; $\mathrm{W}_{2}$ is weight of sample and crucible; $\mathrm{W}_{3}$ is weight of ash and crucible.

\section{Crude protein}

The Kjeldahl method described by Kirk and Sawyer was used to determine the crude protein content by assuming that all protein in the sample contains $14 \%$ nitrogen [23]. It was then calculated using equation 3 .

$$
\% \text { protein }=\frac{\left(V_{2}-V_{1}\right) M_{H C l}}{W} \times 14 \times 6.25 \times 100 \quad \text { Equation } 3
$$

Where:

$\mathrm{V}_{2}=$ Volume $(\mathrm{ml})$ of hydrochloric acid solution required for the test sample

$\mathrm{V}_{1}=$ Volume of hydrochloric acid required for the blank test

$\mathrm{M}_{\mathrm{HCL}}=$ Morality of hydrochloric acid

$\mathrm{W}=$ Weight in grams of test sample

$6.25=$ Nitrogen conversion factor of protein

$14=$ Atomic mass of nitrogen 


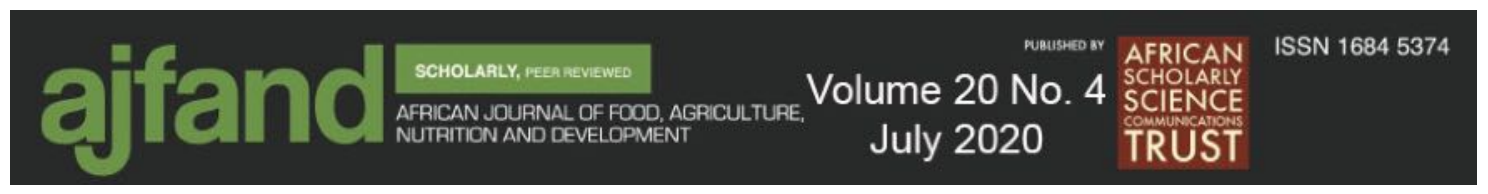

\section{Crude fat}

Fat was determined using the Soxhlet extraction method using equation 4 [21].

$$
\text { Totalfat }(\%)=\frac{W_{1}-W_{2}}{W_{0}} \times 100 \quad \text { Equation } 4
$$

Where: $\mathrm{W}_{0}=$ Weight of the sample $(\mathrm{g}) ; \mathrm{W}_{2}=$ Weight of the empty beaker $(\mathrm{g})$ and $\mathrm{W}_{1}=$ Weight of the beaker and fat $(\mathrm{g})$.

\section{Dietary fibre}

Fibre was determined using Kirk and Sawyer method using equation 5 [23].

$$
\text { Dietaryfibre }(\%)=\frac{W_{1}-W_{2}}{W_{s}} \times 100 \quad \text { Equation } 5
$$

Where: $\mathrm{W}_{2}=$ Weight of dry sinter-glass $(\mathrm{g})$ and $\mathrm{W}_{1}=$ Weight of dry sinter-glass and sample $(\mathrm{g})$ and $\mathrm{W}_{\mathrm{s}}=$ weight of the sample.

\section{Carbohydrate}

Carbohydrate was determined according to Nielsen [24]. The concentration of total sugars was calculated using equation 6.

Concentration $(g / 100 g)=\frac{(\text { Absorbance }- \text { Intercept on vertical axis }) \times \mathrm{D} \times \mathrm{Vo} \times \mathrm{Vi}}{\text { Sample weight }(\mathrm{g}) \times \text { Slope } \times \mathrm{V} \times 10}$ Equation 6

Where: $\mathrm{D}=$ Dilution factor

$10=$ a conversion factor from $\mathrm{mg} / 100 \mathrm{~g}$ to $\mathrm{g} / 100 \mathrm{~g}$

$\mathrm{V}=$ volume of sample pipetted in $\mathrm{ml}$

$\mathrm{V}_{0}=$ final volume of sample diluted up to $100 \mathrm{ml}$ mark

$\mathrm{Vi}=$ Total volume

\section{Gross energy}

The gross energy is the amount of heat produced from unit sample when it is completely burnt down to its ultimate oxidation products (carbon dioxide and water). The sample was burnt in a closed container (Bomb Calorimeter) and the heat produced from it was measured [25]. The gross energy was determined using equation 7.

$$
\text { GrossEnergy }(\mathrm{Cal} / \mathrm{g})=\frac{T x W-(C 1+C 2+C 3)}{M} \quad \text { Equation } 7
$$

Where:

$\mathrm{T}=$ Rise in temperature

$\mathrm{W}=$ Water equivalent

$\mathrm{M}=$ Weight of sample 


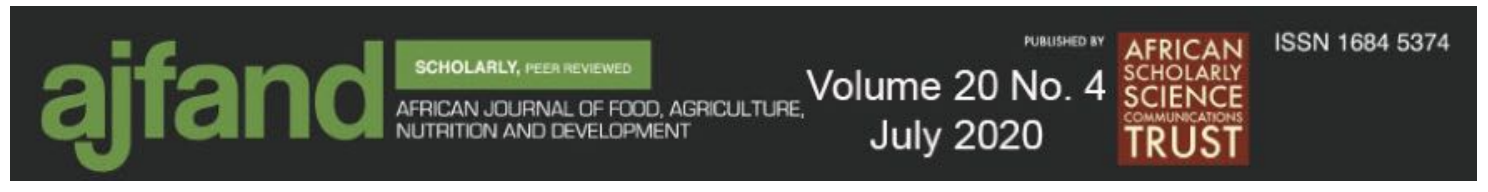

\section{Ascorbic acid}

Ascorbic acid was determined according to Kirk and Sawyer [23]. The content of ascorbic acid content was calculated using equation 8 .

Ascorbic acid $(\mathrm{mg} / 100 \mathrm{~g})=$ Titre $\times \mathrm{VE} \times \mathrm{V}_{1} \times 100 \times 100 / \mathrm{V}_{2} \times \mathrm{S} \times 1000 \times \mathrm{Y} \quad$ Equation 8

Where: $\mathrm{VE}=$ Ascorbic Acid content equivalent of $1 \mathrm{ml}$ of DCPIP $(\mathrm{mg} / \mathrm{ml})$

$\mathrm{V}_{1}=$ Total extract volume $(\mathrm{ml})$

$\mathrm{V}_{2}=$ Titrated extract volume $(\mathrm{ml})$

$\mathrm{S}=$ Sample weight

$\mathrm{Y}=$ Sample dry matter $(\%)$

\section{Beta-Carotene}

Beta-Carotene was determined following De Ritter and Purcell [26] method. It was calculated using equation 9.

$\beta$-carotene content $(\mu \mathrm{g} / 100 \mathrm{~g})=($ observed $\beta$-carotene content $(\mu \mathrm{g} / \mathrm{ml}) \times \mathrm{V} \times \mathrm{D} \times$

$100 \times 100) /(\mathrm{W} \times \mathrm{Y})$.

Equation 9

Where:

$$
\begin{aligned}
& V=\text { total extract volume } \\
& D=\text { dilution factor } \\
& W=\text { sample weight } \\
& Y=\text { dry matter content of the sample }(\%)
\end{aligned}
$$

\section{Data analysis}

The Relative Frequency of Citation (RFC) was used to prioritize the five wild edible plant species for laboratory analysis. It was determined for each species as the ratio of respondents who mentioned a particular species to the total number of respondents in the study [27]. The results of macro-element composition, ascorbic acid and beta-carotene were expressed as means \pm standard deviation. The variation in these means was analysed using one-way Analysis of Variance (ANOVA) at $\mathrm{P}<0.05$ in Statistical Package for the Social Sciences (SPSS) version 16.0 software. The means were compared with the Recommended Daily Allowance (RDA) and Adequate Intake (AI) values [28].

\section{RESULTS AND DISCUSSION}

\section{Priority wild edible plant species}

The Fabaceae family with two species was recognised as one of the widespread and economically important sources of food in the tropics [29]. The collection of young leaves in the four species is less detrimental to the survival of the plant compared to the collection of tubers in Dioscorea sp. However, the former also becomes deleterious when it involves lopping of branches in order to access the young leaves. This was observed in M. angolensis in Onyurut forest reserve.

The conservation status of these five species has not been assessed, both nationally and globally. However, the local community opine that Dioscorea sp. and M. angolensis are 


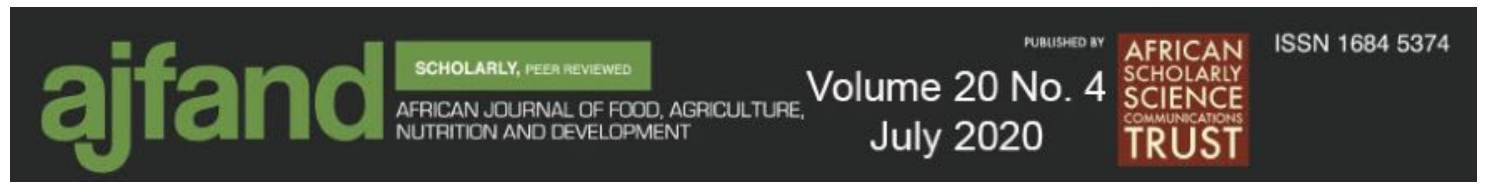

not readily available even during their peak season. The other three species are considered readily available because of the short distance covered and time required to collect them. Uganda faces a high rate of natural vegetation loss [16]. This equally affects the wild edible plants. It is, thus, crucial to conduct national level as well as global conservation assessments of species (like these wild edible species) in order to guide the formulation of appropriate conservation action plans.

\section{Macro-element composition of wild edible plants}

The average macro element composition, ascorbic acid and beta-carotene content for each wild edible plant is shown in Table 2. All these parameters showed a significant difference between plant species $(\mathrm{P}=0.001)$ in a One-Way ANOVA test at $\mathrm{P}<0.05$.

The moisture content determines the propensity of micro-organisms to grow and the shelf life of food material [20]. All the wild edible plants used as leafy vegetables in this region have moisture content values ranging from $59-80 \%$ (Table 2 ), which is within the usual range of $60-83 \%$ moisture content for vegetables. These values are lower than those reported for Vigna unguiculata (L.) Walp (83.66\%) and Amaranthus spinosus L. (84.67\%) [20]. The moisture content of Dioscorea sp. (59.36\%) is almost identical to that of Manihot esculenta Crantz (59.68\%) reported by USDA [30].

The Adequate Intake for dietary fibre ranges from 19-29 g per day for different life stages and groups [28]. Therefore, consuming $100 \mathrm{~g}$ of L. hastata $(27.93 \pm 0.85 \mathrm{~g} / 100 \mathrm{~g})$ per day supplies the AI for normal laxation in adults. The dietary fibre in these plants is superior to $V$. unguiculata $(1.6 \mathrm{~g} / 100 \mathrm{~g})$, A. spinosus $(3.06 \mathrm{~g} / 100 \mathrm{~g})$ and M. esculenta $(1.8 \mathrm{~g} / 100 \mathrm{~g})$ $[20,30]$. The dietary fibre for L. hastata $27.93 \pm 0.85$ reported in this study is superior to $24.06 \pm 2.10 \mathrm{~g} / 100 \mathrm{~g}$ in North Western Uganda [14]. This can be attributed to variation in climatic and edaphic factors.

The RDA of carbohydrates for different life stages and groups between 1-70 years ranges from 130 to $210 \mathrm{~g}$ per day [28]. This implies that consumption of $200 \mathrm{~g}$ of Dioscorea sp. daily can meet the daily carbohydrate needs of healthy individuals aged 1-70 years. The carbohydrate content of the four leafy vegetables in this region is superior to that of $V$. unguiculata (4.40 g/100 g) and A. spinosus (6.66 g/100 g) [20]. In addition, the carbohydrate content of Dioscorea sp. $(65.42 \mathrm{~g} / 100 \mathrm{~g})$ is superior to that of M. esculenta $(38.06 \mathrm{~g} / 100 \mathrm{~g})$ [30].

Ash content is the residue after burning and it represents the total amount of minerals within a food [24]. The lowest ash content was recorded in Dioscorea sp. (0.63 g/100 g), while the highest was in $M$. angolensis $(3.95 \mathrm{~g} / 100 \mathrm{~g})$. These values are comparable to $1.6 \mathrm{~g} / 100 \mathrm{~g}$ in $V$. unguiculata and $3.06 \mathrm{~g} / 100 \mathrm{~g}$ in A. spinosus [20].

The AI crude fat values for infants between 0-12 months is $30-31 \mathrm{~g}$ per day [28]. This is higher than the values obtained for all the wild edible plants from Teso-Karamoja region. These species, therefore, have a low potential for meeting the RDA or AI for fat. This was also observed in earlier findings that leafy vegetables are generally poor sources of fat [20]. With the exception of Dioscorea sp., the other four species have superior crude 


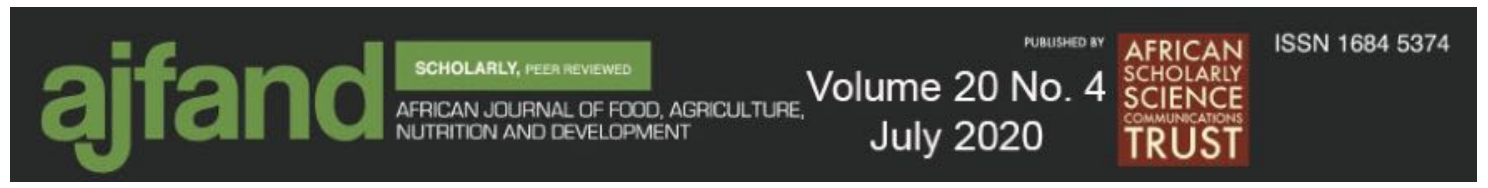

fat content to $0.28 \mathrm{~g} / 100 \mathrm{~g}$ in M. esculenta, $0.52 \mathrm{~g} / 100 \mathrm{~g}$ in A. spinosus and $0.42 \mathrm{~g} / 100 \mathrm{~g}$ in $V$. unguiculata [20,30].

These five wild edible plants make a vital contribution towards protein intake in TesoKaramoja region. For example, consuming $200 \mathrm{~g}$ of M. angolensis $(36.39 \mathrm{~g} / 100 \mathrm{~g})$ is able to supply the RDA (71g per day) for a lactating mother for a day. Similarly, consuming $100 \mathrm{~g}$ of L. hastata $(19.16 \mathrm{~g} / 100 \mathrm{~g})$ per day can sufficiently meet the RDA ( $19 \mathrm{~g}$ per day) of a healthy child aged 4-8 years. The protein content of these wild edible plant species is superior to $V$. unguiculata $(4.54 \mathrm{~g} / 100 \mathrm{~g}$, A. spinosus $(3.57 \mathrm{~g} / 100 \mathrm{~g})$ [20] and $M$. esculenta $(1.36 \mathrm{~g} / 100 \mathrm{~g})$ [30]. The RDA of protein for different life stages and groups ranges from 13 to $71 \mathrm{~g}$ per day [28].

The energy content of all the species investigated in this study is inferior to M. esculenta (160 Kcal), V. unguiculata $(31.22 \mathrm{Kcal})$ and $A$. spinosus $(30.73 \mathrm{Kcal})[20,30]$. It should also be noted that there is no RDA for energy because energy intake above the Estimated Energy Requirement (EER) would result in weight gain [28]. The EER is the average dietary energy intake that is predicted in a healthy adult of a defined age, gender, weight, height and physical activity consistent with good health [28].

\section{Ascorbic acid and beta-carotene}

The RDA of ascorbic acid for different life stages and groups aged 1-70 years is 15-120 mg per day [28]. The wild edible plants from Teso-Karamoja region make a vital contribution to ascorbic acid intake in this region (Table 2). For instance, consuming 100 $\mathrm{g} M$. angolensis $(14.72 \mathrm{mg} / 100 \mathrm{~g})$ daily can ably meet the RDA of individuals aged 1-3 years [28]. The ascorbic acid content of these five wild edible plants is superior to $V$. unguiculata (4.7 mg/100 g) but inferior to A. spinosus (35.01 mg/100 g) [20].

Beta-Carotene is a provitamin A carotenoid. While there is no RDA for beta-carotene, the RDA for vitamin A for different life stages and groups aged 1-70 years is $300-1300 \mu \mathrm{g}$ retinol activity equivalents per day [28]. The four leafy vegetables in Teso-Karamoja region. Therefore, make a vital contribution towards beta-carotene intake. Consuming $100 \mathrm{~g}$ of $S$. obtusifolia provides $1082 \mu \mathrm{g}$. In comparison to $V$. unguiculata $(5880 \mu \mathrm{g})$ and A. spinosus $(1100 \mu \mathrm{g})$, the five species investigated in this study are inferior in terms of beta-carotene [20].

\section{CONCLUSION}

The five wild edible plants from Teso-Karamoja region have a significantly variable nutritional value. The macro-element composition, ascorbic acid and beta-carotene in these plants are either superior, inferior or comparable to those of cultivated crops. The consumption of some of the wild edible plants in ideal quantities can contribute to attainment of the RDA and AI for certain nutritional values for different life stages and groups and contribute to alleviation of malnutrition. There is need to investigate the micronutrients of global public health significance, such as iron and zinc, anti-nutrient factors, and potential toxic compounds of these plants. This information will further elucidate their role in enhancing food and nutrition security as well as ensuring the safety of the consumers. 


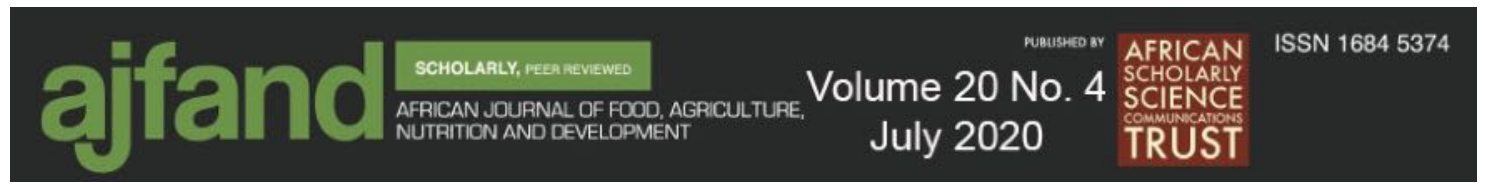

\section{ACKNOWLEDGEMENT}

This study was supported by the German Academic Exchange Service (DAAD) InCountry/In-Region programme PhD scholarship to Samuel Ojelel (Grant no. 91636693).

\section{CONFLICT OF INTEREST}

The authors declare no conflict of interest 


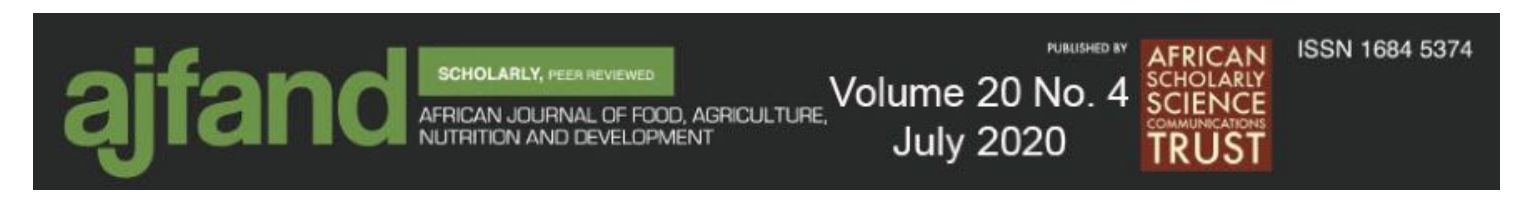

Table 1: Five priority wild edible plant species from Teso-Karamoja region, Uganda

\begin{tabular}{llllll}
\hline \multicolumn{1}{c}{ Family } & \multicolumn{1}{c}{ Scientific name } & Local name & RFC & Lifeform & Edible parts \\
\hline Apocynaceae & $\begin{array}{l}\text { Leptadenia hastata } \text { (Schumach. \& } \\
\text { Thonn.) Decne }\end{array}$ & Eimongo* & 0.06 & Climber & Leaves \\
Dioscoreaceae & Dioscorea sp. & Pwomu $^{* *}$ & 0.19 & Climber & Tubers \\
Capparaceae & Maerua angolensis DC. & Edioli $^{*}$ & 0.20 & Shrub & Leaves \\
Fabaceae & Vigna kirkii (Baker) J.B. Gillett & Ediila/Emaret $^{*}$ & 0.03 & Climber & Leaves \\
& Senna obtusifolia (L.) H.S. Irwin \& & Eedo*Oyado** $^{* *} 0.03$ & Forb & Leaves \\
& Barneby & & & & \\
\hline
\end{tabular}

Key: RFC=Relative frequency of citation, ${ }^{*}$ Ateso/Ngakirimongg, ${ }^{* *}$ Acholi-Labwor 


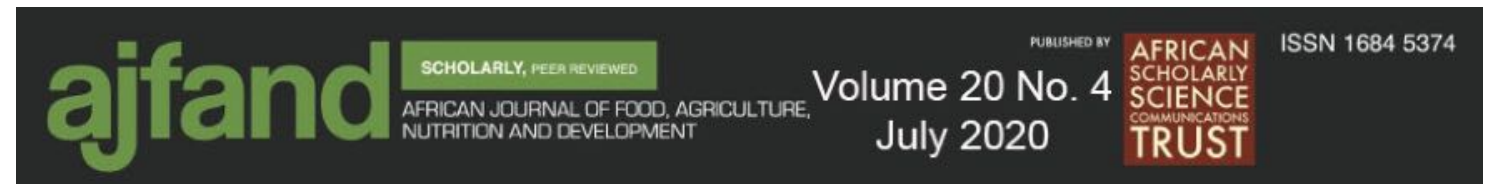

Table 2: Macro-element, ascorbic acid and beta-carotene content of wild edible plants in Teso-Karamoja region, Uganda

\begin{tabular}{|c|c|c|c|c|c|c|c|}
\hline \multirow[b]{2}{*}{ Parameter (/100g) } & \multicolumn{7}{|c|}{ Wild edible plant species } \\
\hline & Leptadenia & Senna & Maerua & Vigna kirkii & Dioscorea sp. & RDA** & $\mathrm{AI} * * *$ \\
\hline & hastata & obtusifolia & angolensis & & & & \\
\hline Moisture content $(\%)^{*}$ & $79.30 \pm 0.20$ & $78.86 \pm 0.38$ & $66.09 \pm 0.19$ & $80.74 \pm 0.34$ & $59.36 \pm 0.82$ & - & - \\
\hline Dietary fibre $(\%)^{*}$ & $27.93 \pm 0.85$ & $16.93 \pm 2.54$ & $12.42 \pm 0.26$ & $21.46 \pm 0.58$ & $2.74 \pm 0.24$ & - & $19-29$ \\
\hline Carbohydrate $(\mathrm{g})^{*}$ & $22.45 \pm 1.96$ & $25.27 \pm 1.18$ & $23.77 \pm 2.02$ & $17.32 \pm 0.40$ & $65.43 \pm 2.91$ & $130-210$ & - \\
\hline Ash content $(\%)^{*}$ & $2.84 \pm 0.10$ & $2.37 \pm 0.10$ & $3.95 \pm 0.23$ & $2.60 \pm 0.01$ & $0.63 \pm 0.03$ & - & - \\
\hline Gross Energy (KCal)* & $18.40 \pm 0.06$ & $19.03 \pm 0.90$ & $19.04 \pm 0.37$ & $18.49 \pm 0.07$ & $16.17 \pm 0.09$ & - & - \\
\hline Crude fat $(\%)^{*}$ & $3.60 \pm 0.13$ & $2.02 \pm 0.09$ & $0.94 \pm 0.03$ & $2.72 \pm 0.18$ & $0.08 \pm 0.02$ & - & 31-ND \\
\hline Crude protein $(\%)^{*}$ & $19.14 \pm 0.26$ & $27.26 \pm 0.12$ & $36.39 \pm 0.42$ & $28.37 \pm 0.42$ & $7.17 \pm 0.17$ & $13-71$ & - \\
\hline Ascorbic acid (mg)* & $6.89 \pm 1.33$ & $10.77 \pm 2.70$ & $14.71 \pm 3.56$ & $7.62 \pm 0.54$ & $8.78 \pm 0.37$ & $15-120$ & - \\
\hline beta-carotene $(\mu \mathrm{g})^{*}$ & $363.54 \pm 0.09$ & $1082.12 \pm 0.08$ & $817.31 \pm 0.05$ & $965.14 \pm 0.01$ & $5.15 \pm 0.01$ & $300-1300$ & - \\
\hline
\end{tabular}

Key: *Means values are significantly different at 0.05 level and are means \pm standard deviation, RDA** means Recommended Daily Allowance and $\mathrm{AI}^{* * *}$ means Adequate Intake. ND means No data. RDA and AI values are adopted from Institute of Medicine (2005) 


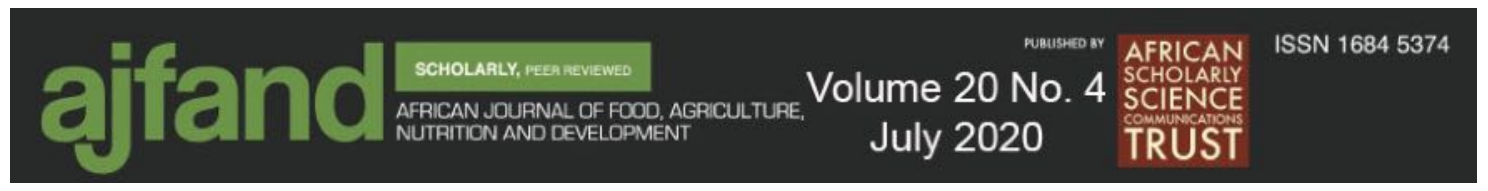

\section{REFERENCES}

1. FAO. The State of Food Security and Nutrition in the World 2017: Building Resilience for Peace and Food Security. Rome, Italy. 2017.

2. IPC. Uganda-Current Acute Food Security Situation: January-March 2017. Integrated Food Security Phase Classification. 2017. www.ipcinfo.org. Accessed 30 March 2018.

3. Vinceti B, Eyzaguirre $\mathbf{P}$ and $\mathbf{T}$ Johns The nutritional role of forest plant foods for rural communities. In: Colfer CJP (ed). Human health and forests: a global overview of issues, practice and policy. Routledge, London, 2008: 63-93.

4. Seal T, Pillai B and K Chaudhuri Nutritional potential of five unexplored wild edible plants consumed by the tribal people of Arunachal Pradesh state in India. International Journal of Food Science and Nutrition. 2017; 2:101-105.

5. Benevides NMB, Holanda ML, Melo FR, Pereira MG, Monteiro ACO and ALP Freitas Purification and partial characterization of the lectin from the marine green alga Caulerpa cupressoides (Vahl) C. Agardh. Botanica Marina. 2001; 44:17-22.

6. Shad AA, Shah HU and $\mathbf{J}$ Bakht Ethnobotanical assessment and nutritive potential of wild food plants. J Anim Plant Sci. 2013; 23:92-7.

7. Getachew GA, Asfaw Z, Singh V, Woldu Z, Baidu-Forson JJ and $\mathbf{S}$ Bhattacharya Dietary values of wild and semi-wild edible plants in Southern Ethiopia. African Journal of Food, Agriculture, Nutrition and Development. 2013; 13:2.

8. Burlingame B Wild nutrition. Journal of Food Composition and Analysis. 2000; 2:99-100.

9. Bhattarai S, Chauldhary RP and RSL Taylor Prioritization and trade of ethnobotanical plants by the people of Manang District, Central Nepal. In: Chauldhary RP, Aase TH, Vetaas OR, Subedi BP (eds). Local effects of global changes in the Himalayas, Manang, Nepal. Tribuvan University and Norway: University of Bergen. 2007; 151-169.

10. Bukenya-Ziraba $\mathbf{R}$ The non-cultivated edible plants of Uganda. NAPRECA monograph series 9. 1996.

11. Kakudidi EK, Bukenya-Ziraba R and JM Kasenene Wild foods from in and around Kibale National Park in Western Uganda. LIDIA. Nor J Bot. 2004; 6:6582. 


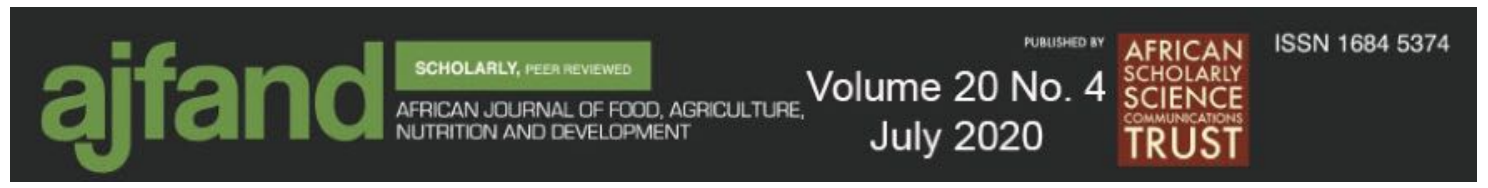

12. Agea JG, Okia CA, Abohassan RAA, Kimondo JM, Obua J, Hall J and $\mathbf{Z}$ Teklehaimanot Wild and semi-wild food plants of Bunyoro-Kitara Kingdom of Uganda: growth forms, collection niches, parts consumed, consumption patterns, main gatherers and consumers. Environmental Research Journal. 2011; 5:74-86.

13. Ojelel S, Mucunguzi P, Katuura E, Kakudidi EK, Namaganda $M$ and J Kalema Wild edible plants used by communities in and around selected forest reserves of Teso-Karamoja region, Uganda. Journal of Ethnobiology and Ethnomedicine. 2019; 15:3.

14. Anywar GU, Oryem-Origa $\mathbf{H}$ and $\mathbf{M}$ Kamatenesi-Mugisha Proximate nutrient composition of some wild edible medicinal plants from Uganda. African Journal of Food, Agriculture, Nutrition and Development. 2017; 17:12215-12226.

15. Drichi P National Biomass Study. Forest Department, Kampala, Uganda. 2003.

16. Egeru A Role of indigenous knowledge in climate change adaptation: A case study of the Teso Sub-Region, Eastern Uganda. Indian Journal of Traditional Knowledge. 2012; 11:217-224.

17. Egeru A, Wasonga O, Kyagulanyi J, Majaliwa GM, MacOpiyo L and $\mathbf{J}$ Mburu Spatio-temporal dynamics of forage and land cover changes in Karamoja sub-region, Uganda. Pastoralism. 2014; 4:6.

18. Bolfarine H, and WO Bussab Elementos de amostragem. São Paulo, Editora Edgar Blücher. 2005.

19. Lykke AM Local perceptions of vegetation change and priorities for conservation of woody-savanna vegetation in Senegal. Journal of Environmental Management. 2000; 59:107-120.

20. Agea JG, Kimondo JM, Woiso DA, Okia CA, Obaa BB, Isubikalu P, Okullo JBL, Obua $\mathbf{J}$ and $\mathbf{Z}$ Teklehaimanot Proximate composition, ascorbic acid and beta-carotene contents of fifteen selected leafy wild and semi-wild food plants (WSWFPs) from Bunyoro-Kitara Kingdom. Uganda. J. Nat. Prod. Plant Resour. $2014 ; 4: 1-12$.

21. AOAC. Official Methods of Analysis of the Association of Analytical Chemists. AOAC International. 2016.

22. AOAC. Official Methods of Analysis of the Association of Analytical Chemists. AOAC International, Arlington. 1996.

23. Kirk RS and R Sawyer Pearson's composition and analysis of foods, $9^{\text {th }}$ edn. Longman Group Limited, UK. 1991.

24. Nielson SS Food analysis. Kluwer Academic/Plenum Publishers, London. 2003. 


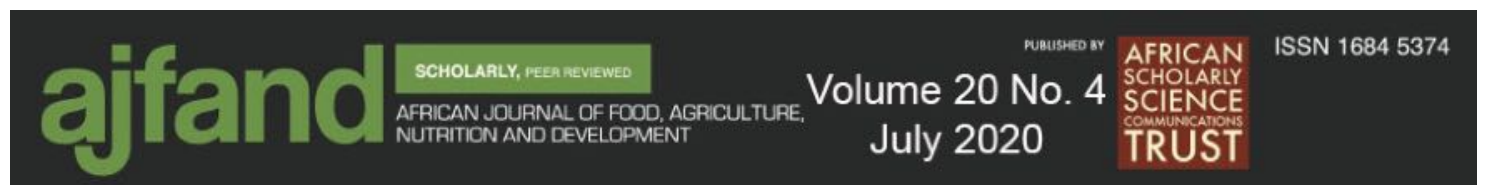

25. AOAC. Official Methods of Analysis of the Association of Analytical Chemists, AOAC International, Washington DC, USA. 1995.

26. De Ritter $\mathbf{E}$ and $\mathbf{A E}$ Purcell Carotenoids analytical methods. In: Bauernfeind JC (ed). Carotenoids as colourants and vitamin A precursors. Academic Inc. London. 1981.

27. Tardío J and M Pardo-de-Santayana Cultural importance indices: a comparative analysis based on the useful wild plants of Southern Cantabria (Northern Spain). Economic Botany. 2008; 62:24-39.

28. Institute of Medicine (IOM) Dietary reference intakes for energy, carbohydrate, fiber, fat, fatty acids, cholesterol, protein, and amino acids (macronutrients). National Academy Press, Washington, DC. 2005.

29. Maroyi A The gathering and consumption of wild edible plants in Nhema Communal Area, Midlands Province, Zimbabwe. Ecol Food Nutr. 2011; 50:506525.

30. USDA. National Nutrient Database for standard reference: Basic report 11154. Cassava raw. https://ndb.nal.usda.gov/ndb/search/list?home=true. 2018. Accessed 10 March 2019. 